
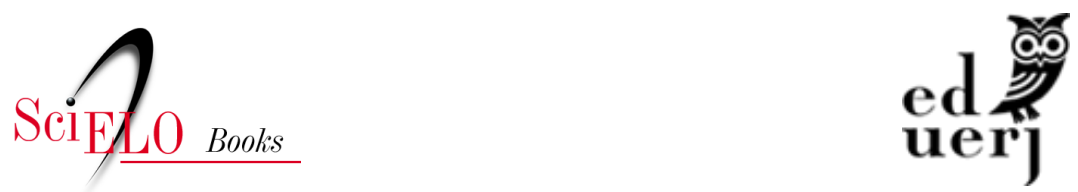

\title{
Teorias de localização: do espaço absoluto e relativo ao espaço relacional
}

Flaviane Ramos dos Santos

Maria Encarnação B. Sposito

\section{SciELO Books / SciELO Livros / SciELO Libros}

SANTOS, F. R., and SPOSITO, M. E. B. Teorias de localização: do espaço absoluto e relativo ao espaço relacional. In.: MAIA, D. S., and MARAFON, G. J., eds. O programa Minha Casa Minha Vida: habitação e produção do espaço urbano em diferentes escalas e perspectivas [online]. Rio de Janeiro: EDUERJ, 2020, pp. 19-51. ISBN: 978-65-00-03029-7.

https://doi.org/10.7476/9786500030297.0002.

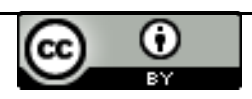

All the contents of this work, except where otherwise noted, is licensed under a Creative Commons Attribution 4.0 International license.

Todo o conteúdo deste trabalho, exceto quando houver ressalva, é publicado sob a licença Creative Commons Atribição 4.0.

Todo el contenido de esta obra, excepto donde se indique lo contrario, está bajo licencia de la licencia Creative Commons Reconocimento 4.0. 


\section{Teorias de localização: do espaço absoluto e relativo ao espaço relacional}

Flaviane Ramos dos Santos

Maria Encarnação B. Sposito

\section{Introdução}

O desenvolvimento de pesquisa relativa ao tema "Grandes infraestruturas urbanas, ensino superior e desenvolvimento regional: reconfigurando as relaçôes entre as cidades médias, as cidades pequenas e o campo" estimulou o grupo que o propôs ${ }^{1}$ a refletir sobre os fatores que orientam a localização espacial. No caso desse projeto em particular, foram destacadas as escolhas locacionais relativas ao Programa Minha Casa Minha Vida (MCMV) e à instalação de instituições de ensino superior, com o objetivo de mostrar as relaçóes entre essas escolhas e as realizadas por grandes agentes econômicos, que levam à implantação de grandes áreas comerciais e de serviços nas cidades estudadas.

Estávamos, então, diante de tripla intenção: a) reconhecer quais são as escolhas feitas pelo poder público (MCMV e universidades públicas); b) as realizadas pela iniciativa privada (especialmente hipermercados, shopping centers e outras grandes superfícies comerciais, além das instituiçóes de ensino superior privadas); c) relacionar duas lógicas que são baseadas em interes-

1 Como já explicitado na apresentação desse livro, trata-se de proposta ao Edital Pró-Integração $\mathrm{n}^{\circ}$ 55/2013, aberto pela Coordenadoria de Aperfeiçoamento do Pessoal do Ensino Superior (CAPES). Este texto, entretanto, além do interesse de contribuir para o projeto, resulta de apoio dado pela Fundação de Amparo à Pesquisa do Estado de São Paulo, para desenvolvimento da tese doutoral de Flaviane Ramos dos Santos (Processo 2017/17632-0), intitulada "Da localização estratégica às estratégias locacionais: A dimensão espacial do crédito e da fidelização nos magazines e nas escolhas dos citadinos em Presidente Prudente (SP) e Londrina (PR)". 
ses diversos (públicos e privados), mas que se inter-relacionam, visto que os agentes políticos e econômicos envolvidos com elas têm articulaçóes ou são as mesmas pessoas, em algumas situaçóes.

Era preciso partir, então, da literatura existente sobre o tema, com destaque para as reflexóes e proposiçóes atinentes aos modelos locacionais. Esse desafio foi enfrentado levando-se em consideraçáo que as ciências são construçóes humanas sujeitas às determinaçóes da época e da sociedade que as produz (Moraes e Costa, 1987). Neste capítulo, apresentamos uma breve contextualizaçáo histórica das principais formulaçóes teóricas e modelos de localização, ressaltando seus princípios e pressupostos, além das diferenças de abordagem de cada um dos autores. Em seguida, questionamos a capacidade e a validade dos modelos locacionais na análise da realidade da distribuiçáo espacial das empresas no período contemporâneo e avaliamos os motivos que levaram à superação (ou não) desses fatores e quais as transformaçóes no espaço geográfico e na sociedade, relacionadas ao progresso técnico, científico e informacional (Santos, 1996) que contribuíram para que isso ocorresse.

No decorrer do capítulo, algumas vezes indicaremos, de um lado, como essas proposiçóes adequam-se ou náo à compreensão do período atual e, de outro, como foram formuladas muito mais para apoiar as lógicas das empresas, ponderar em que medida ajudam a analisar ou criticar as opçóes feitas pelo poder público.

Dado o caráter geral do texto, não voltado diretamente à análise do material empírico da pesquisa apoiada pela CAPES, esperamos que o leitor faça as mediaçóes necessárias à articulação entre essas reflexóes e os dados da realidade que aparecem nos outros capítulos, bem como com outras pesquisas que vêm sendo realizadas.

Entender a localização das atividades no espaço urbano tem levado pesquisadores, há várias décadas, a se interessar pelo estudo dos modelos locacionais e a realizar discussão sobre sua relevância para a compreensão e a análise da problemática da localização das atividades econômicas, sendo esse interesse fundamental para entendimento do processo pelo qual os investimentos são direcionados no espaço geográfico e quais os fatores condicionantes dessa decisão.

Tendo em vista as limitaçóes que apresentam, estes modelos devem ser analisados a partir de uma perspectiva crítica, sendo que algumas se dirigem às suposiçóes feitas na sua construção, tais como o postulado da 
racionalidade dos agentes econômicos e o princípio da maximização de lucros. Outras referem-se aos fatores locacionais considerados pelos modelos que, basicamente, são os custos de transporte, de mão de obra e dos insumos. Outros ainda são direcionados à suposição do espaço como sendo homogêneo e, por último, a não consideração das estruturas de mercado não concorrenciais.

Durante certo tempo, os modelos, enquanto representação idealizada do mundo real, tornaram-se um instrumento bastante utilizado na análise da organização espacial, permitindo melhor compreensão da realidade. Sua construção avançou por dois caminhos distintos. O primeiro é aquele em que o problema começava com postulados muito simples e uma maior complexidade era introduzida gradualmente, aproximando o modelo cada vez mais da realidade, enquanto o segundo consistia em resumir a realidade mediante uma série de generalizaçóes, muitas vezes simplificadoras.

Haggett (1976) questiona os motivos que levaram à utilização dos modelos nas teorias de localização, tendo em vista que, no caso de alguns, eles são mais fáceis de refutar do que de confirmar. Assim, o autor destaca, primeiro, que a construçáo de modelos foi inevitável porque não existe uma linha divisória entre fatos e crenças. Segundo, que a construção de modelos é econômica, porque permite transmitir uma informação generalizada de forma muito simplificada. E, por último, a construção de modelos era estimulante, porque suas generalizaçóes colocam em destaque alguns elementos que necessitam de aperfeiçoamentos e, com isso, conduzem a posteriores modificaçóes. Em síntese, o papel dos modelos consiste em sintetizar o que já ocorreu e em orientar açôes que incidirão sobre a realidade.

Em que medida esses modelos, ainda que criticados e, parcialmente, refutados têm ainda orientado empresas e o poder público no momento das decisóes concernentes à localização de investimentos relativos a empreendimentos econômicos ou a políticas públicas? Essa questáo, mesmo que não respondida de modo cabal, pode orientar o leitor a nos acompanhar nas ideias que passamos a apresentar. 


\section{Teorias de Localização: De Von Thunen à Walter Isard}

A preocupação com a questáo locacional começou a ser pensada de modo sistemático somente com a emergência e o desenvolvimento do modo capitalista de produção (Corrêa, 1986), entre a segunda metade do século XVI e início do século XVII, na Inglaterra. Com a Revolução Industrial no final do século XVIII, o capitalismo alcançou um estágio mais avançado, tendo em vista que, a partir desse momento, o capital acumulado no comércio podia ser reproduzido e ampliado por meio do investimento na produçáo (compra de matéria-prima, ferramentas, máquinas e força de trabalho) e na apropriação de parte da riqueza produzida pelo trabalhador e não remunerada a ele - a mais valia (Dobb, 1980). A busca pela acumulação cada vez maior de capital promoveu transformaçóes significativas, até então nunca vistas como, por exemplo, mudanças no papel e estruturação do espaço interno das cidades e a ampliação da divisão social e territorial do trabalho.

A lógica capitalista, caracterizada pela minimizaçáo de custos e maximização de lucros, suscitou aumento da escala de produção. Com isso, nessa nova fase, a localização das atividades econômicas e da população passou a ter importância fundamental para os interesses da classe dominante, porque diante dos volumosos investimentos de capital acumulado no comércio em atividades de produçáo, circulaçáo e distribuição, o aumento dos lucros poderia ser resultado de ganhos diferenciais relacionados às vantagens locacionais (proximidade com as fontes de energia, matéria-prima, infraestrutura, meios de transporte, reservas de força de trabalho, mercado consumidor etc.) (Corrêa, 1986). Em outras palavras, a localização começou a ter enorme significado quando passou a representar um dos elementos que influenciava os custos de produção e os lucros e, portanto, a capacidade de sucesso do empreendimento no capitalismo concorrencial.

Os primeiros a teorizarem sistematicamente sobre a localização das atividades econômicas foram Johann Heinrich Von Thünen (1826), Alfred Weber (1909), Walter Christaller (1933), August Losch (1939) e Walter Isard (1956). Embora analisem atividades diferentes - isto é, agricultura, indústria e comércio -, todos eles consideram os custos dos transportes como fator fundamental na análise locacional, tendo como princípio básico a racionalidade baseada no comportamento otimizador do agente econômico por meio da minimização dos custos e/ou maximização dos lucros (Richardson, 1975). 
De maneira sintética, a seguir, apresentaremos as formulações e modelos teóricos elaborados por cada um dos autores supracitados, começando pelo economista e proprietário de terras no norte da Alemanha, Johann Heinrich Von Thünen, que publicou sua obra "O estado isolado em relação com a agricultura e a economia" (Der isolierte staat in beziehung auf landwirtschaft und nationalökonomie) em dois volumes: o primeiro, em 1826, e o segundo, em 1863 (Corrêa, 1986), na qual ele se preocupa com a influência da cidade sobre a formaçáo dos preços dos produtos agrícolas e a influência da distância da cidade sobre a renda dos agricultores (Azzoni, 1982). Por muitos autores, ele é considerado como o pioneiro da teoria de localizaçáo.

$\mathrm{Na}$ época em que suas proposiçóes foram elaboradas, estavam ocorrendo mudanças na organização espacial da agricultura em determinadas áreas da Europa, com a passagem de uma agricultura camponesa, de subsistência e venda de excedentes, para uma agricultura de mercado, na qual se reafirmava a propriedade privada e o trabalho assalariado (Corrêa, 1986). Deste modo, Von Thünen procurou descrever o que seria o uso mais racional da terra e como deveria ser a organização espacial da agricultura no âmbito da economia capitalista.

Segundo Camagni (2005), para elaboração de suas ideias, Von Thünen imaginou um estado isolado onde os fatores físicos não variavam, todas as terras seriam igualmente planas e férteis, haveria somente um meio de transporte primitivo terrestre e em linha reta e uma grande cidade no centro, acessível por todos os lados e cujos habitantes consumissem todos os produtos agrícolas. Calculando os custos de transporte e os custos de exploraçáo, Von Thünen estabeleceu a disposição dos cultivos na forma de anéis/círculos concêntricos em torno da cidade, visto que a diferenciaçáo no uso agrícola da terra se dá em virtude dos custos crescentes de transporte de cada produto cultivado, à medida que a distância do mercado consumidor aumenta (Figura 1).

A renda territorial, excedente disponível depois de ter remunerado todos os fatores de exploração, deve ser maximizada. Contudo, seu nível depende do tipo de produçấo, da quantidade produzida e da distância do mercado. Assim, em uma planície uniforme e de igual fertilidade, com uma só cidade no centro, a renda se dá em função da natureza da produção e do distanciamento do mercado (Bailly, 1978, p. 30). 
Figura 1 - Anéis de Thünen

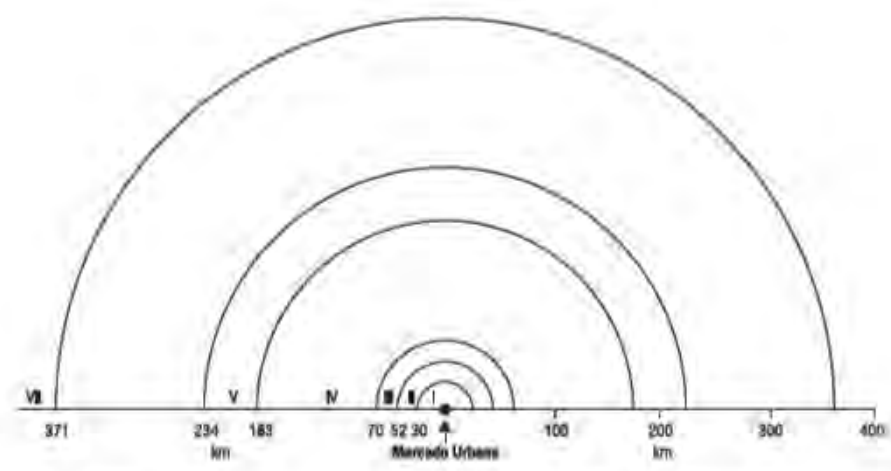

I Horticultura intensiva

II Silvicultura

V Sistema de três campos

III Sistema rotativo de cereais e raizes

IV Sistema rotativo de cultura e pastagem

VI Criação de gado

VII Floresta virgem

Fonte: Braga (2008)

$\mathrm{Na}$ sua concepção, os produtos pesados, volumosos e os perecíveis seriam encontrados próximos à cidade e os de fácil transporte, mais distantes. Assim, o primeiro anel, mais interno, estava voltado para produtos que não suportavam um transporte demorado, como verduras, flores e leite; no segundo anel temos a silvicultura; no terceiro havia o cultivo de diversos cereais (milho, trigo, centeio etc.) e tubérculos; o quarto, muito largo, era utilizado para agricultura e pastagem por rotação de culturas; no quinto, surge o sistema de três campos com o alqueive; no sexto, igualmente muito largo, temos criação extensiva; e fora destas zonas estava a floresta virgem (Braga, 2008).

Em síntese, a preocupação central de Von Thünen era determinar a composição de culturas que maximizasse a renda da terra, levando em consideração a distância do centro consumidor e o tipo de cultivo. Ao fornecer instrumentos para compreensão da estrutura espacial da agricultura e suas associaçóes com a cidade, o modelo de Von Thünen inspirou diversos outros trabalhos, notadamente em Economia Urbana, além de se constituir no marco inicial das discussóes espaciais no âmbito econômico, dando subsídios para outras perspectivas espaciais. Contudo, por se tratar de uma teoria que aborda a localização de atividades agrícolas, sendo muito influenciada por fatores climáticos e fenômenos da natureza, essa abordagem é bastante restritiva quando comparada com os outros modelos de localização (Azzoni, 1982). 
Assim, embora se trate de formulação importante na história da construção do pensamento sobre fatores de localização, ela, independentemente de seu valor como teoria, pouco oferece de elementos para se analisar as escolhas locacionais no espaço urbano. Entretanto, no que se refere aos capítulos contidos nesse livro, em que as relaçóes entre a cidade e o campo são importantes, o leitor poderá encontrar aportes que serão valiosos nessa perspectiva.

O segundo autor a se preocupar com a localização de atividades econômicas foi o sociólogo e economista alemáo Alfred Weber, que em 1909 publicou o livro "Teoria da Localização das Indústrias" (Über den Standort der Industrie), no qual analisa as atividades industriais e a influência dos custos de transportes, da máo de obra e das forças aglomerativas tendo como princípio básico a minimizaçáo do custo de transporte através da localização ótima da indústria, que ocorre quando há um equilíbrio entre a localização das matérias primas, do centro consumidor e da mão de obra (Azzoni, 1982).

Em sua formulação teórica, Weber adota os seguintes pressupostos e suposiçóes gerais: a localização das matérias-primas, a posição e o tamanho dos centros de consumo são dados e conhecidos; a mão de obra pode ser encontrada em oferta ilimitada a uma taxa de salário determinada em várias localizaçóes dadas e fixas; as condiçôes físicas e técnicas da superfície são homogêneas e; os custos de transporte variam em funçáo do peso e da distância do mercado (Braga, 2008). Além disso, implicitamente em toda a sua obra estáo os pressupostos da concorrência perfeita (ideia de que cada produtor detém um mercado ilimitado, sem possibilidade de obter vantagens monopolísticas de sua escolha locacional) e dos coeficientes fixos de produçáo (Azzoni, 1982).

Para determinar a localização ótima da indústria, Weber analisou separadamente a influência dos custos de transportes, da máo de obra e dos fatores aglomerativos. No primeiro caso, ele considerou um cenário em que existem duas matérias-primas necessárias e localizadas em dois pontos distintos e um centro consumidor, situado em um terceiro ponto. Esses três pontos formam o que denominou de triângulo locacional (Figura 2), no qual a interseçáo das circunferências dentro do triângulo locacional determina o ponto de custo mínimo de transporte (Coutinho, 2009).

Nos outros dois casos, utilizou como instrumento de análise as curvas isodapanas (iso - igual, dapanas - custos ou despesas), que permitem visualizar o padrão de variação espacial dos custos (Figura 3). A ideia era que a atividade produtiva fosse atraída na direção da localidade em que o custo de mão 
de obra fosse mais barato e favorável ao produtor, desde que essa localidade se situasse dentro da isodapana crítica (aquela na qual o custo de transporte se equilibra com a economia de gastos com máo de obra). Caso contrário, a indústria permaneceria localizada no ponto que oferece custo mínimo de transporte (Coutinho, 2009).

Figura 2 - Triângulo Locacional

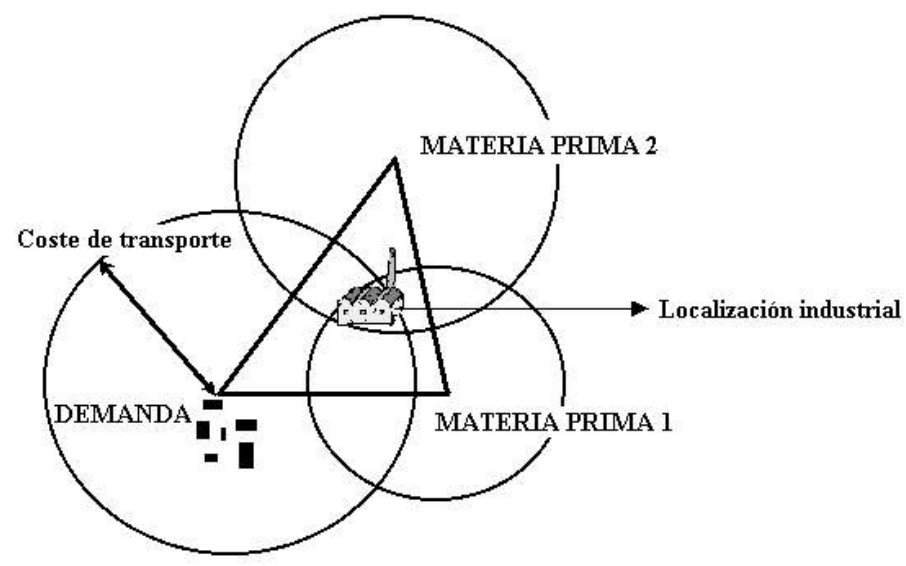

Fonte: Braga (2008)

Figura 3 - Curvas Isodapanas

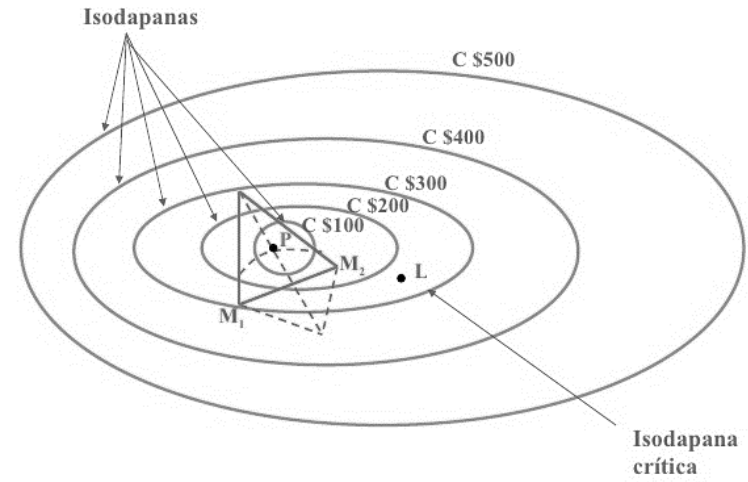

Fonte: Braga (2008) 
A partir do exposto, é possível observar que esse modelo reflete características essenciais dos processos de industrialização e urbanização do século XIX, no qual o custo de transporte constitui o principal fator de influência na escolha da localização das atividades econômicas, além da mão de obra e os fatores aglomerativos que, isolados ou em conjunto, podem compensar o fator preço de transporte no processo de minimizaçáo de custo para determinar a localização ótima da indústria (Camagni, 2005). No que se refere à pesquisa que gera esse livro, o enfoque recaiu, no espaço urbano, na atividade do setor comercial e de serviços, mas é possível considerar que aspectos associados ao peso dos transportes têm seu impacto sobre esse setor, uma vez que, no tocante ao comércio, a distância entre os centros de produçáo e armazenamento de produtos industriais, sobretudo, é elemento importante para a decisão das empresas no que se refere à presença delas em cidades médias e pequenas, onde o tamanho do mercado consumidor tem que ser ponderado vis-à-vis aos custos de instalação comercial e aos custos adicionais do transporte de bens.

Em que sejam pesados esses pontos, como possibilidades de se aproveitar elementos da formulação de Weber, uma das principais críticas a essa abordagem consiste nos seus pressupostos teóricos limitados e pouco adequados a situaçóes reais, o que dificulta sua comprovação empírica, além da náo-abordagem do lado da demanda, que é considerada como dada e independente da localização da indústria, não havendo, portanto, uma análise dela (Coutinho, 2009). Além disso, de acordo com Camagni (2005, p. 34),

O modelo weberiano responde a um enfoque de equilíbrio parcial, no qual não existe interação nos comportamentos empresariais e é um modelo estático, no qual se tem em conta sobretudo a eficiência produtiva, mas deixa-se de lado, ao menos no nível mais formalizado, os processos evolutivos, tanto no nível microeconômico (inovaçóes) quanto macroeconômico (dinâmica das condiçôes de distribuição de renda e relaçóes entre benefícios de aglomeração, rendas e salários).

Esse modelo recebeu várias críticas e aperfeiçoamentos posteriores. Em síntese, tanto para Weber quanto para Von Thünen, a localização ótima era aquela que proporcionasse menor custo em transportes - da matéria-prima para as indústrias e dos produtos para o consumidor. Contudo, uma dife- 
rença básica entre os dois autores é que enquanto Von Thünen procura responder quais atividades deverão se localizar em determinado local, Weber procura mostrar onde se localiza uma determinada atividade industrial.

A mais importante contribuição no estudo da localização de atividades econômicas foi do geógrafo alemão Walter Christaller que, em 1933, publicou a obra "Os Lugares Centrais no Sul da Alemanha" ("Die zentralen Orte in Süddeutschland”), na qual formulou uma teoria com o objetivo principal de não apenas explicar a organização espacial dos núcleos de povoamento e das suas áreas de influência, mas identificar as leis gerais que determinavam os padróes de povoamento que observava à sua volta e, deste modo, classificou as localidades de acordo com as suas funçóes e analisou as relaçóes entre elas e suas áreas de influência (Bradford e Kent, 1987).

Não podemos nos contentar com o esclarecimento das relaçóes com que se pode explicar o tamanho, o número e a distribuiçáo dos lugares centrais em casos concretos individuais. Estamos em busca de leis que trazem ordem a distribuição aparentemente arbitrária, ao número aparentemente acidental, e aos tamanhos aparentemente só condicionados individualmente dos lugares. (Christaller, 1966, p. 106) ${ }^{2}$

Christaller preocupou-se mais com a posição relativa, que seria a posição ocupada por uma localidade em relação a outras localidades, sendo expressa em tempo, percurso, custo de transporte etc., do que com a posição absoluta dos "lugares" centrais (Fajardo, 2010). Assim, sua teoria ficou conhecida como Teoria das Lugares Centrais (ou Teoria das Localidades Centrais), ${ }^{3}$ que aborda localização, tamanho, natureza e distribuição espacial do comércio e serviços e, durante muito tempo, se constituiu como a base teórica de uma grande parte da Geografia Urbana (Berry, 1971), influenciando notadamente vários autores. Contudo, na época de publicação, a obra não teve muita repercussão; só com o passar das décadas, sobretudo após sua

2 Sempre referindo-se à tradução de Eufrásio (1981).

3 Na tradução realizada por Eufrásio (1981), a expressão utilizada é "lugares centrais". Contudo, no Brasil, tanto a expressão "lugares centrais" quanto a expressáo "localidades centrais" pode ser encontrada nas publicaçóes que discorrem sobre a teoria elaborada por Christaller. Tendo em vista que o conceito de lugar compreende vivência, pertencimento e identidade, optamos por utilizar "localidades centrais", embora nas situaçóes em que o autor citado use "lugar", respeitamos a expressáo escolhida por ele e colocamos "aspas". 
tradução para o inglês, em 1966 (com o título "Central Places in Southern Germany"), é que veio finalmente a ser reconhecida por suas contribuiçóes.

Segundo a teoria, as localidades apresentam determinadas funçóes centrais que atraem os consumidores do entorno dependendo do custo de deslocamento. Essas localidades foram hierarquizadas entre si em função de dois mecanismos básicos: o alcance espacial máximo e o alcance espacial mínimo. No primeiro, tem-se um raio a partir da localidade central até onde os consumidores estáo dispostos a se deslocar para obter determinados bens e serviços. No segundo caso, tem-se a área mínima para que determinada função central possa se instalar lucrativamente (Braga, 2008). Tais mecanismos poderiam ser considerados para a análise das escolhas locacionais relativas aos usos de solo que foram estudados na pesquisa da qual esse livro resultou. Quando pensamos na localização das universidades, por exemplo, sem dúvida não se pode apenas avaliar a escala da cidade, porque grande parte de seus alunos são oriundos das cidades menores em seu raio de polarização, sendo que uma parcela deles se desloca diariamente para acompanhar seus cursos de formação na localidade central onde está a unidade universitária a que se vinculam. Num país como o Brasil, os mecanismos de alcance espacial máximo e alcance espacial mínimo têm que ser matizados pela incompletude ou ineficácia de nosso sistema de circulação interurbana, seja em decorrência das infraestruturas (sobretudo rodoviárias) e dos meios de transporte (principalmente os coletivos).

Esses pontos têm relação direta com outros aspectos da mesma formulação. Christaller baseou sua teoria em um conjunto de pressupostos, sendo que cada um deles foi expresso implícita ou explicitamente. Segundo Bradford e Kent (1987), o primeiro deles é a concepção da existência de uma planície uniforme na qual a população está igualmente distribuída e há igual facilidade de transporte em todas as direçóes, sendo os custos proporcionais à distância. Além disso, presume-se que todos os consumidores têm o mesmo rendimento, demanda igual pelos bens e serviços e que eles sempre se deslocam à localidade central mais próxima que forneça o bem ou serviço que procuram; ou seja, pressupóe-se a racionalidade por parte do consumidor em minimizar a distância que deve percorrer para satisfazer suas necessidades. Ao aplicar uma concepção como essa à realidade brasileira, defronta-se com a amplitude de nossas desigualdades socioespaciais. De todo modo, independente de maior ou menor grau de desigualdade, é bom lembrar que, 
conforme Hagget (1983), o modelo é representação idealizada e nos exemplos utilizados para ilustrar suas proposiçôes teóricas, Christaller faz algumas simplificaçôes da realidade bastante questionáveis, inclusive para o período em que foi elaborado. A partir do enunciado a seguir, por exemplo, podemos identificar algumas dessas simplificações:

Suponhamos uma regiáo de aproximadamente $80 \mathrm{~km}^{2}$ que tenha quatro mil habitantes uniformemente distribuídos por toda a região, exceto num pequeno lugar em que a população tende a se aglomerar. Suponhamos que um médico, a fim de oferecer seu serviço central nessa região, se estabeleça no centro da regiáo. A demanda de serviços médico é basicamente a mesma por toda a população, isto é, cada habitante tem aproximadamente o mesmo número de doenças ou distúrbios. Ademais, suponhamos que todas as pessoas dessa regiāo tenham rendas iguais que permitam destinar 6 marcos [moeda oficial da Alemanha até 2002, antes da adesão ao euro] por pessoa por ano para despesas médicas, após as outras necessidades prementes, tais como alimentação, vestuário e habitação, terem sido satisfeitas (Christaller, 1966, p. 47, grifos nossos).

De acordo com Bradford e Kent (1987), a racionalidade econômica também é esperada por parte do fornecedor/produtor na medida em que se pressupóe que ele tem como único objetivo maximizar seu lucro, localizando-se de maneira a obter o maior mercado consumidor possível. Uma vez que as pessoas se deslocam ao centro mais próximo, os fornecedores localizam-se o mais longe possível uns dos outros, maximizando as suas áreas de mercado. Em relação a esse ponto, as particularidades das cidades médias brasileiras também levariam à contestaçáo desse primado, visto que, em grande parte, sendo marcadas por clara separação espacial entre ricos e pobres, as empresas comerciais voltadas a segmentos socioeconômicos médios e altos tendem a se localizar no mesmo setor da cidade, impondo aos que ganham menos a necessidade de se deslocarem por distâncias maiores entre suas residências e áreas de comércio e serviços, ${ }^{4}$ na mesma cidade ou em cidades diferentes, se quiserem ter acesso a certos produtos (bens ou serviços) e a espaços de consumo de mais prestígio social.

4 Para esse debate é importante a reflexão sobre a ideia de distância econômica que será abordada logo adiante. 
De acordo com a teoria, grandes, médias, pequenas cidades e até mesmo vilas rurais são consideradas como localidades centrais, dotadas de funçóes centrais, ou seja, bens e serviços destinados à população tanto da cidade como de seu entorno (área de influência ou regiáo complementar). A centralidade de cada localidade seria determinada pelo grau de importância de suas funçóes centrais, e para cada produto ou serviço haveria, em princípio, um alcance espacial específico, ou seja, a distância que as pessoas estariam dispostas a percorrer para adquirir algo. Assim, estabelece-se uma hierarquização dos centros no que diz respeito à oferta de bens e serviços.

O alcance espacial depende de certas variáveis, como distribuiçáo da população, distâncias econômicas a serem percorridas, tipos de bens ${ }^{6}$ etc., e cada bem tem um alcance específico, que pode variar em certos casos. $\mathrm{O}$ alcance de um bem central se constitui em um anel cujo limite superior é a distância mais afastada da localidade central em que ele pode ser adquirido e cujo limite inferior é a distância em que ocorre o montante mínimo de vendas para que sua produçáo e oferta seja compensadora.

O limite superior e limite inferior juntos determinam se um bem central pode ser oferecido em qualquer lugar central da regiáo com alguma chance de sucesso. O limite inferior circunscreve a região com o menor número de vendas que deve existir para se oferecer o bem central num lugar central dessa regiáo, enquanto o limite superior circunscreve aquela região em que a venda do bem central pode ser possível de qualquer modo. Isso significa que ambos os limites determinam a menor área e a maior região complementar de um lugar central com relação a um certo bem central. Esses limites se desenvol-

5 Christaller (1966) atribui mais importância ao que denomina de "distância econômica", ou seja, a distância relativa a tempo e custo, do que à distância em quilômetros. Inclusive afirma que a distância econômica possui elementos objetivos como, por exemplo, custos de frete, perdas de peso, danos eventuais causados por uma viagem mais demorada etc., e subjetivos, tais como, comodidade e conveniência.

6 Em relação aos tipos de bens, Christaller (1966) destaca a existência de quatro tipos: produtos com quantidade limitada e preço fixo; produtos com quantidade limitada e preço variável; produtos com quantidade ilimitada e preço fixo e, por último, produtos com quantidade ilimitada e preço variável. $\mathrm{O}$ autor descreve de que forma o preço e o alcance do produto afetam o desenvolvimento do "lugar" central, isto é, os bens com alcances semelhantes são oferecidos pelos mesmos "lugares" centrais. Quanto menor o alcance, maior será o número de "lugares centrais" que vendem esse bem e o inverso também é verdadeiro. 
vem em curvas fechadas, que se aproximam mais ou menos do círculo, e que se constituem em isolinhas (Christaller, 1966, pp. 109-10).

De acordo com Camagni (2005), a hipótese de Christaller era a de que a rede urbana se constituía a partir das zonas de influência econômica das localidades, cuja centralidade seria determinada pelo nível de complexidade dos produtos e serviços ali ofertados e, também, a partir do alcance desses mercados. Estes produtos e serviços, por sua vez, estariam classificados como de ordem superior ou de ordem inferior, indo dos mais aos menos especializados, e essa classificação também definiria os aglomerados. Em geral, "lugares centrais" de ordem superior abarcam outros, de ordem inferior, configurando relaçóes espaciais de interdependência assimétrica, ou seja, haveria uma forma de organização hierárquica em que as cidades pequenas se subordinam às cidades médias e estas às grandes, tal como mostra a Figura 4. Tais relaçóes permitem vislumbrar o estabelecimento de uma hierarquia de "lugares centrais", na qual os "lugares" de ordem mais elevada são mais populosos, porém menos numerosos, enquanto os "lugares" de ordem mais baixa são menores demograficamente e mais numerosos (Valbuena, 2013).

A abordagem teórica de Christaller realça a formaçáo de uma rede de centros urbanos com diferentes tamanhos e importâncias, do ponto de vista funcional. Cada localidade central tem a sua região complementar ou área de influência, que tem sempre o formato hexagonal, porque

se o território deve ser servido por uma rede perfeitamente uniforme de lugares centrais, então não haverá nem demasiado muitos nem demasiado poucos lugares deste tipo, e também não haverá nenhuma parte não suprida, entáo os lugares centrais contíguos devem estar equidistantes uns dos outros. (Christaller, 1966, p.115, grifo nosso). 
Figura 4 - Sistema de "lugares centrais" com diferentes níveis hierárquicos

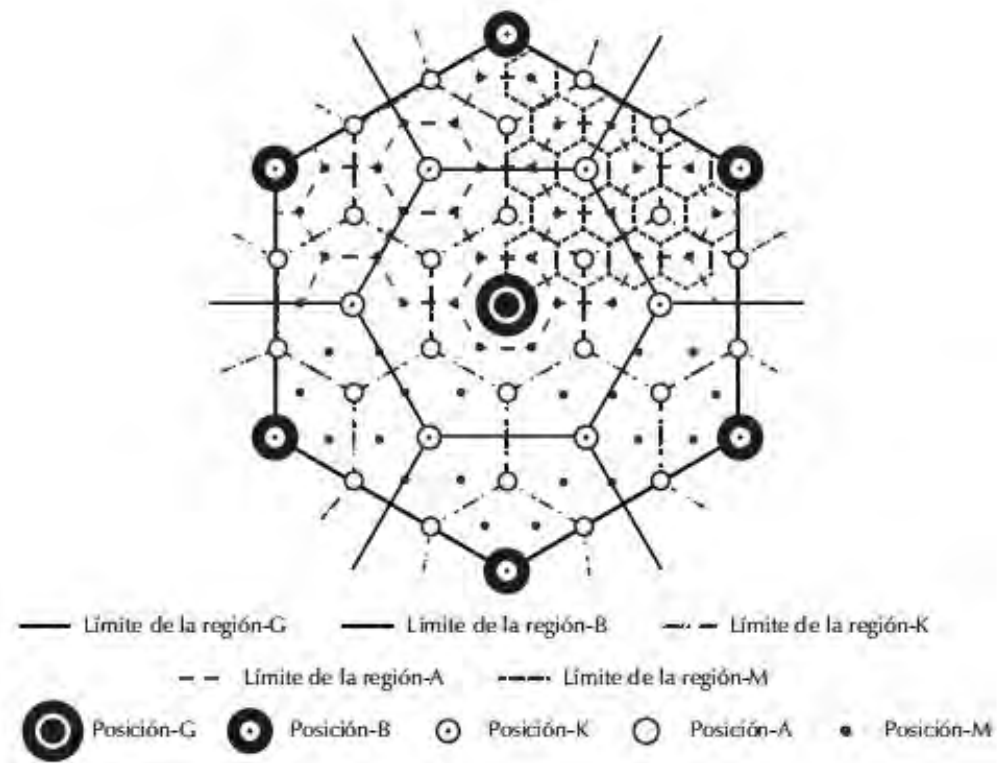

Fonte: Valbuena (2013, p. 86)

Sobre essa questáo, Bradford e Kent (1987) afirmam que, para assegurar que todos os consumidores sejam servidos, os fornecedores aproximam-se uns dos outros e, com isso, as áreas circulares de mercado interceptam-se. Considerando o pressuposto já explicado de que os consumidores das áreas sobrepostas preferem deslocar-se para o centro mais próximo, as áreas de mercado resultantes serão, então, hexagonais. Christaller (1981 [1933]) admite a possibilidade de haver o que ele chama de desvios do normal e afirma que esses desvios são sempre decorrentes de causas definidas que podem ser justificadas. Portanto, de acordo com a teoria, esse padrão hexagonal é o modo mais eficiente de organizaçáo das áreas de mercado de forma que sejam servidos todos os possíveis clientes. 
Para Christaller (1981 [1933]), as localidades centrais são organizadas de acordo com três princípios: ${ }^{7}$ o de mercado, que abarca as relaçóes existentes entre as localidades centrais de diferentes níveis hierárquicos; o de tráfego ou circulação, que prevê que as localidades centrais estejam alinhadas sobre rotas diretas de circulaçáo que se abrem em leque a partir do ponto central; e o administrativo, que considera os limites territoriais dos centros e determina a influência das localidades de ordem superior sobre aqueles de ordem inferior. A seguir, apresentamos as figuras 5, 6 e 7 que mostram o sistema de localidades centrais baseado nos três princípios supracitados.

Figura 5 - Princípios de mercado, de tráfego e administrativo

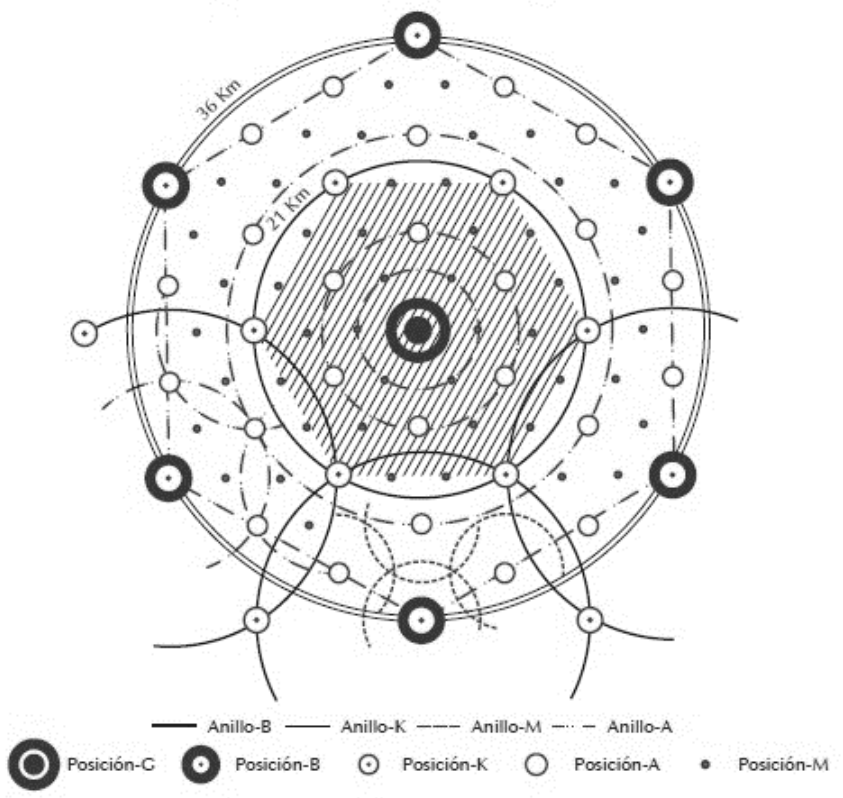

7 Para saber mais, consultar Bradford e Kent (1987) e Valbuena (2013). 
Figura 6 - Princípios de mercado, de tráfego e administrativo

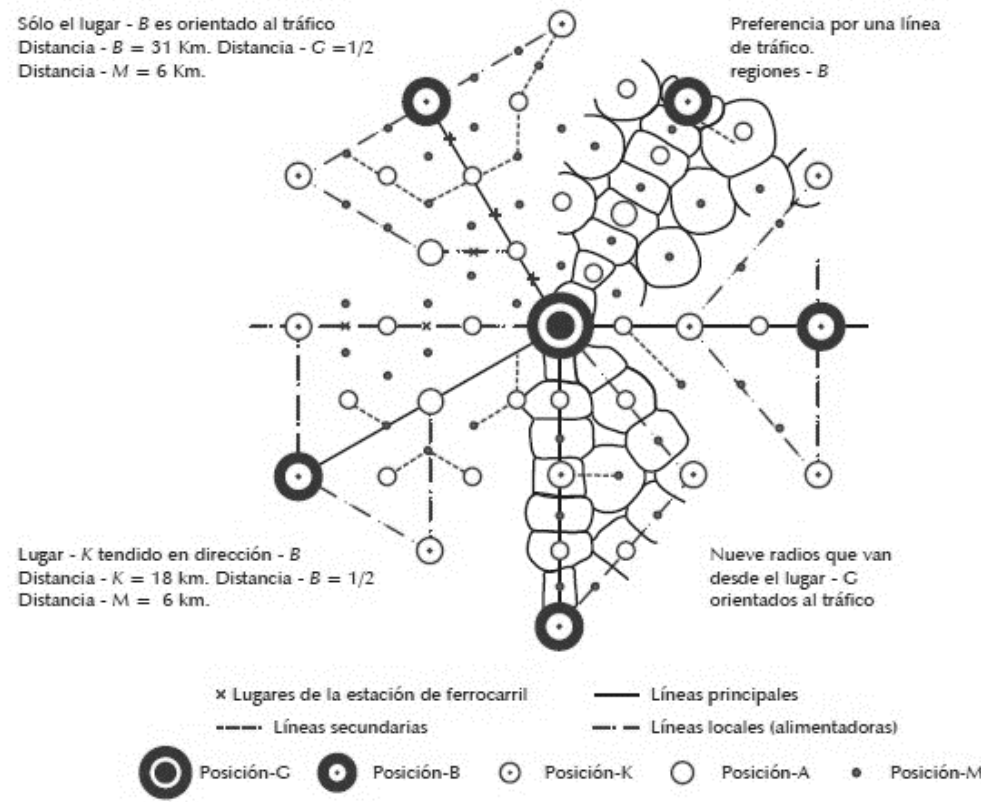

Figura 7 - Princípios de mercado, de tráfego e administrativo

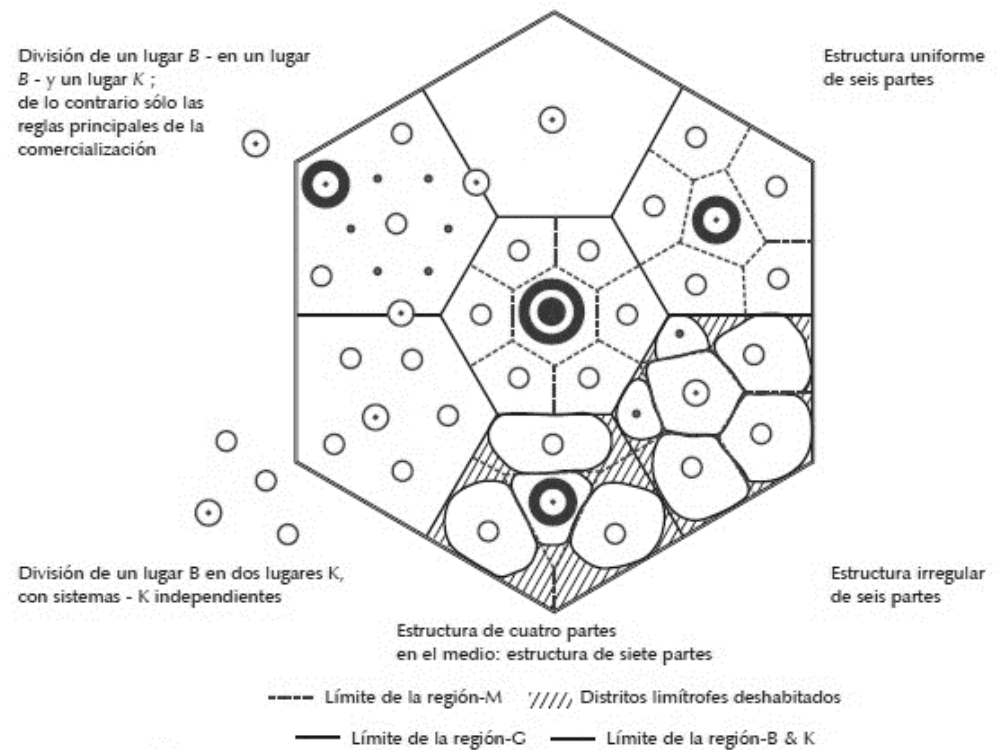
(O)
Posición-C
(-) Posición-B
$\odot$ Posición-K
Posición-A
Posición-M

Fonte: Valbuena (2013, pp. 89, 91 e 93) 
Dependendo das características da região, tais como nível de desenvolvimento, densidade e renda da população, entre outros aspectos, o princípio de tráfego pode ter um peso maior que supera o princípio de mercado ou vice-versa. Sobre essa questão Christaller afirma que:

Somente um território densamente povoado, com bom nível de vida, com população gozando de um alto nível de cultura e que seja principalmente industrial, pode suportar muitos lugares centrais; aqui, consequentemente, o princípio de circulação [tráfego] pode levar vantagem. Regiôes agrícolas densamente povoadas e mais pobres, de outro lado, consomem menos bens centrais e podem suportar poucos lugares centrais. Uma racionalidade mais alta é mais provável de ser obtida com um número mínimo de lugares centrais; portanto, o princípio de abastecimento [mercado] prevalece (Christaller, 1966, p. 138).

Segundo Christaller (1981 [1933]), a diferença fundamental entre o princípio de circulação e o princípio de mercado é que o primeiro é linear e o último atua de modo bidimensional. Em relação ao princípio administrativo, o autor afirma que este tem natureza completamente diferente dos anteriores, em razão da ordem centralista que lhe é característica, ou seja, ao redor do núcleo principal de ordem mais elevada, haveria uma coroa de localidades de menor importância e, em direção à periferia da região, uma densidade de população que vai diminuindo. Portanto, os três princípios determinam, cada um de acordo com suas próprias leis, os sistemas de localidades centrais. Os dois primeiros são econômicos e o terceiro é político. No que concerne ao princípio administrativo, mais uma vez, por meio desse livro, é possível questionar sua aplicabilidade às nossas cidades, nas quais, via de regra, sobretudo nas área de programas habitacionais com finalidade social, como o MCMV, a tendência é exatamente outra, pois a densidade de grandes conjuntos habitacionais é elevada e, paralelamente, as áreas centrais e pericentrais têm perdido prestígio e população nas últimas décadas.

Apesar de sua contribuição, diante de uma realidade mais complexa do que os pressupostos admitidos por Christaller, algumas de suas ideias já não se confirmavam nem sequer na realidade do século XX. Conforme apontam Bradford e Kent (1987), algumas das inconsistências lógicas de sua formulação teórica dizem respeito à distribuição uniforme da população e igualdade 
na capacidade de consumo; facilidade de transporte em todas as direções; a existência de áreas de mercado de dimensóes semelhantes no padrão de hexágonos perfeitos; relação perfeita entre o número e a dimensão dos centros; comportamento não realista dos consumidores (racionalidade econômica), presumindo que eles se deslocavam somente para os locais mais próximos, e também dos fornecedores, como se eles fossem incapazes de criar monopólios espaciais e que devido à concorrência as áreas de mercado se sobrepusessem.

Em relação aos diferentes níveis hierárquicos das cidades, Christaller (1981 [1933]) não incluiu algumas funçôes que também geravam emprego e população, como, por exemplo, a indústria. Uma possível justificativa para isso é a industrialização incipiente na porção sul da Alemanha (região analisada pelo autor), pois embora o país tenha começado a se industrializar no final do século XIX, esse processo foi bastante concentrado no Vale Ruhr (porção oeste), devido à sua posição estratégica do ponto de vista do escoamento da produção, à presença significativa de hulha (um tipo de carvão mineral) e à condição favorável dos nobres da região (Braga, 1999).

Entretanto, é importante ressaltar que não considerar a indústria não significa que ela tenha sido completamente ignorada pelo autor. Apesar do que muitos afirmam, Christaller náo ignorou nem os recursos naturais ${ }^{8} \mathrm{e}$ nem o papel da indústria como uma das maiores influências no sistema de localidades centrais, ele destacou, inclusive, que a localização industrial é responsável, juntamente com outros fatores, pelo direcionamento da expansão e desenvolvimento ou contração da regiáo complementar.

A opção por não incluir as indústrias em seu modelo é decorrente da ideia de que, no que concerne à produção, Christaller (1981 [1933]) afirma que raramente ocorre em "lugares centrais", porque as desvantagens são maiores que as vantagens, ou seja, os fatores desaglomerativos superam os fatores de aglomeração. Isso acontece porque os custos de produção são maio-

8 Considerando que, historicamente, as cidades surgem ao longo dos rios, Christaller (1981 [1933]), utilizou o exemplo de uma cidade próxima de um rio e uma cidade distante, para afirmar que o alcance dos bens oferecidos na primeira cidade é maior assim como sua região complementar, em razáo do custo de transporte fluvial ser mais barato. No caso de um "lugar central" próximo de um rio e isolado, o alcance espacial (mínimo e máximo) tem o formato de anéis, porém, no caso de haver "lugares centrais" vizinhos do outro lado da margem do rio, a área de influência e o alcance espacial assume a forma elíptica. Portanto, Christaller não somente considera os recursos naturais, como também destaca que o custo é variável de acordo com o modal de transporte. 
res em consequência dos salários mais altos e do preço do solo/imóveis mais elevados nos "lugares centrais". Deste modo, o autor afirma que não é a produção de bens, mas a oferta deles e a prestação de serviços que são vinculadas aos "lugares centrais".

Nesse sentido, Sposito (2007 e 2018) afirma que associar a indústria e o crescimento do urbano não é tâo direta como alguns autores estabelecem, especialmente aqueles que associaram esses dois processos para teorizar sobre desenvolvimento econômico. Segundo a autora, na maior parte dos casos, o desenvolvimento urbano não ocorre necessariamente após a chegada das indústrias, mas após a chegada dos produtos industriais destinados ao consumo dos citadinos. Em outras palavras, sobretudo hoje, o consumo associado à distribuição de bens e serviços explica muito mais a centralidade urbana do que a indústria. Embora a chegada e presença de indústrias seja importante, é o comércio e os serviços que mais oferecem emprego e geração de renda, além de ser o setor que promove maior movimentação de pessoas no espaço urbano, tendo em vista sua relação mais próxima e direta com os consumidores. ${ }^{9}$

Para Christaller (1981 [1933]), em contraposição aos "lugares centrais" estão os lugares dispersos, ou seja, todos aqueles que não são pontos centrais. Eles podem ser: a) vinculados a áreas, como por exemplo aquelas localidades cujos habitantes vivem de suas atividades agrícolas; b) vinculados a pontos, tais como aquelas localidades cujos habitantes desenvolvem uma atividade a partir de condiçóes presentes em determinado local, como a mineração; ou c) localidades que são indiferentes à sua localização como, por exemplo, as grandes indústrias, cujas posiçóes são determinadas por certas vantagens econômicas (reservas de mão de obra, vias de transporte etc.). Assim, as indústrias estão situadas no que Christaller classificou como lugares dispersos, que não são o foco de sua obra.

Levando em conta que a distribuição das atividades industriais não era uniforme no espaço geográfico, mas sim, muitas vezes, concentrada em determinados localidades, sua localização não seguia o pressuposto de Christaller. Além disso, como se intensifica o processo de industrialização em período posterior, surgiram várias empresas prestadoras de serviços para a indústria, situadas nas mesmas localizaçóes (Bradford e Kent, 1987). Conforme vere-

9 Isso que explica, por exemplo, porque cidades bastante industriais no estado de Sáo Paulo, como Americana, Limeira ou São Carlos, são menos importantes, do ponto de vista da hierarquia urbana, do que Presidente Prudente. 
mos a seguir, a formulação elaborada por Losch mostra-se mais realista para o caso das indústrias.

É importante destacar que, na formulação de Christaller, não é considerado o papel dos agentes econômicos e públicos na influência da distribuição, dimensões e funções das localidades centrais, tendo em vista que são os responsáveis, entre outras coisas, por determinar a direção da expansão e do desenvolvimento da cidade, além de oferecer vantagens para instalação de empresas e indústrias. Isso é decorrente, como já ressaltamos, da concepção de espaço vigente e utilizada pelo autor, além da influência da corrente do pensamento geográfico no qual está, ainda que indiretamente, inserido. ${ }^{10}$ Portanto, apesar de sua importância para a Geografia Urbana e Regional, a Teoria das Localidades Centrais deve ser analisada criticamente e com cuidado, pois alguns de seus princípios e pressupostos não são mais válidos e outros, ainda, podem ser questionados, até mesmo tomando como referência o período de sua elaboração.

Seguindo a exposição dos autores que se preocuparam com a localização de atividades econômicas, temos o economista alemão August Losch, que publicou a obra intitulada "A economia de localização" (Die Wirtschaftlichkeit des Standortes, edição original em alemão de 1939 e a edição inglesa, The economics of location, de 1967), na qual elabora uma teoria geral do equilíbrio das localizaçóes em um sistema econômico, estudando as relaçóes de interdependência existentes entre as localizaçôes individuais e o equilíbrio espacial geral (Bailly, 1978). Sua teoria dedicou especial atenção à definição das áreas de mercado, tendo como fator determinante da escolha da localização a maximizaçáo do lucro dos produtores, divergindo neste ponto de Christaller, para quem o determinante é a minimização dos custos de deslocamento dos consumidores. É importante ressaltar que a Teoria do Equilíbrio Locacional de Losch possui algumas hipóteses e pressupostos semelhantes aos que já foram apresentados em relação à formulação teórica elaborada por Christaller. Segundo Ablas (1982), é incontestável que Losch tenha se baseado, ao menos nas ideias principais, no trabalho de Christaller.

Segundo Losch, "nem a minimização de custos, nem a maximização de receitas leva à localização ótima, o que é apenas possível pela consideração da

${ }^{10}$ Em Santos (2018), situamos os modelos locacionais no respectivo contexto histórico e geográfico em que foram pensados e elaborados, tendo em vista que suas influências sobre o raciocínio dos autores são, de certa forma, bastante significativas. 
maximização de lucros" (Azzoni, 1982, p. 21). Além disso, Losch concentra-se mais na análise a partir da demanda, relegando a segundo plano as variaçôes de custo e considerando a maximização dos lucros como fundamental para determinar a localização ótima. Em outras palavras, ao contrário de seus antecessores, Losch acreditava que a escolha locacional deveria ser pautada na busca pelo maior lucro possível e não no menor custo possível.

De acordo com Azzoni (1982), a explicação de Losch para o sistema de cidades baseia-se em um raciocínio puramente econômico, tendo como principais pressupostos a concepção de espaço como planície isotrópica, isto é, superfície plana e homogênea na qual as matérias-primas estão distribuídas uniformemente e as possibilidades de transporte são iguais em todas as direçôes, resultando na regularidade de custos. Além disso, considerou também que a população está distribuída igualmente pela superfície e que os gostos e preferências dos consumidores são idênticos (Richardson, 1975), não considerando, portanto, as desigualdades sociais que redundam em diferenciação na capacidade e oportunidades de consumo.

Partindo do pressuposto de que os custos são iguais em todas as direçôes, Losch preocupou-se em analisar a demanda. Essa é outra importante diferença em relação aos seus antecessores, que se preocupam com a oferta. Deste modo, ao introduzir a demanda nas teorias de localização, Losch admitiu que "a elasticidade da curva de demanda varia segundo as regióes, conforme a preferência dos consumidores e, principalmente, de acordo com o seu poder aquisitivo" (Donda Jr., 2002, p. 34).

Ao centrar a sua análise na disputa por mercados, Losch afirmou que as empresas têm a oportunidade de auferirem mais lucros se diversificarem seus produtos e conseguirem manter a exclusividade de mercados. De acordo com Ablas (1982), o raciocínio de Losch partiu das variáveis econômicas que determinam a área de abrangência do mercado para um determinado bem, da mesma forma como o fez Christaller. No entanto, ele a inicia por meio da caracterização da curva de demanda de um consumidor individual para, em seguida, transpor essa formulação para o espaço e introduzir o custo de transporte. Assim, Losch concebe uma planície de áreas hexagonais de mercado, na qual as empresas buscam explorar adequadamente o cone de demanda e cujo tamanho varia em função dos custos de transporte.

Ao comparar o raciocínio de Losch com as proposiçóes de Christaller, Ablas (1982) destaca que, na essência, todas as conclusôes tiradas pelo pri- 
meiro estavam presentes na análise do segundo, sobretudo se lembrarmos do exemplo dos serviços médicos que apresentamos anteriormente quando falamos das simplificações da realidade bastante questionáveis de Christaller. "A única diferença possível entre as duas abordagens diz respeito à forma de apresentação. Losch procura incorporar na sua análise os conceitos de teoria econômica até entáo desenvolvidos, tornando-a mais facilmente compreensível, ao menos para os economistas" (Ablas, 1982, p. 69).

De acordo com Bailly (1978), as principais diferenças em relação às duas formulações teóricas dizem respeito, primeiro, à definição da dimensão ideal do hexágono e das áreas de influência e, segundo, que enquanto Losch parte da menor área de mercado para elaborar seu esquema e introduzir áreas de influência cada vez mais amplas, Christaller parte do "lugar central" de maior ordem para, em seguida, alcançar os lugares de níveis inferiores na hierarquia. O percurso do pensamento é, portanto, inverso. Outra notável diferença é que, para Christaller, "lugares centrais" de uma dada ordem podem oferecer todos os bens de "lugares" de ordem inferior a essa, enquanto Losch entende que a especialização torna possível que lugares centrais de ordem inferior possam oferecer produtos e serviços para "lugares centrais" de ordem mais elevada. Essa distinção de Losch em relação a Christaller pode ser valiosa para tratarmos sobre a localizaçáo das unidades de ensino superior, pois, no Brasil, no período dos Governos Federais de Luís Inácio Lula da Silva e Dilma Rousseff, houve efetiva tendência de interiorização da oferta desse nível de formação e pesquisa, com força em áreas urbanas não metropolitanas. É necessário que haja um tempo maior para se ter mais condiçôes de avaliar em que medida lugares centrais de ordem inferior, no caso desse serviço, estarão atendendo demandas de lugares centrais de ordem mais elevada.

Independente desse aspecto, Bailly (1978) acrescenta que as duas obras apresentam também, basicamente, as mesmas lacunas ou fraquezas, tais como a não previsão dos deslocamentos da população e do consumo realizado fora da planície; a afirmaçáo de que todos os empregadores e compradores procedem da área de mercado; não consideram os custos do espaço, fator que modifica os custos de produçáo e de oferecimento de serviços e; suposiçáo de que o comportamento de consumidores e produtores é sempre racional.

Richardson (1975) reconhece que, apesar de suas limitaçóes, a teoria geral de Losch deve ser reconhecida por ter sido a primeira tentativa de descrever relaçóes espaciais por meio de equaçóes simples e por apresentar 
um modelo de economia espacial, operado em condiçóes de concorrência monopolista. Além disso, a formulação proposta por Losch é considerada por alguns autores como mais sistemática e precisa por incluir um raciocínio em termos de teoria econômica que conduz a análise de forma mais suave e rigorosa (Ablas, 1982).

A seguir, apresentamos o economista norte-americano Walter Isard, considerado como o último grande expoente da teoria clássica de localização. Em 1957, publicou a obra "Localização e espaço econômico: uma teoria geral relacionada com a localização industrial" (Location and Space-economy: a general theory relating to industrial location), na qual sintetiza as teorias anteriores e propóe um modelo mais geral e abrangente, analisando a localizaçáo das atividades industriais. Sua grande contribuição foi relacionar a questáo locacional ao desenvolvimento regional, trazendo à tona novos aportes teóricos e temáticos - tais como a questáo ambiental, os valores culturais e o contexto político - como importantes para a definição dos tipos de atividades e a localização delas no espaço (Alves, 2015).

A importância do estudo da economia de localização é decorrente da existência de regularidades nas variaçóes de custos e preços no espaço geográfico, que emergem fundamentalmente, porque o custo de transporte é proporcional à distância (Donda Jr., 2002). Em sua formulação, Isard considera os fatores locacionais apenas pelo lado dos custos, conferindo grande importância aos custos de transporte, de transmissão e de produção. Além disso, tal como os autores dos modelos anteriores (com exceção de Losch), baseia-se na minimização de custos para determinar uma localizaçáo ótima (Coutinho, 2009).

De acordo com Bailly (1978), Isard teve um papel importante no aperfeiçoamento das formulaçóes teóricas de Christaller e Losch ao afirmar que a área de mercado das localidades centrais não se dá somente em função da distância máxima a que os consumidores estão dispostos a percorrer, mas pela densidade de consumidores. Constatou também que a dimensão das áreas de mercado é menor nas zonas mais populosas e o custo de transporte não se limita às áreas de mercado, a não ser que a densidade seja muito baixa.

Contudo, Isard não conseguiu solucionar uma das principais contradições da formulação teórica de Christaller, que consiste na relação nem sempre clara entre a dimensão das localidades centrais e o tamanho de sua populaçáo (Bailly, 1978). Sobre essa questão, o geógrafo norte-americano Brian Berry 
(1971), a partir de um conjunto de verificaçóes empíricas, constatou que o aumento da mobilidade das pessoas fez com que algumas cidades tivessem excesso de funçóes em relação à sua população. Em outras palavras, algumas cidades norte-americanas apresentavam funçóes muito abaixo ou muito acima ao esperado, considerando o tamanho de sua população, o que acontecia por várias razóes. Entre elas, o autor destaca as cidades-dormitórios, os centros históricos ou turísticos, ou ainda as cidades recém-criadas (Bradford e Kent, 1987).

Brian Berry publicou, em 1967, a obra "Geography of Market Centers and Retail Distribution" (traduzida para o espanhol em 1971 com o título "Geografía de los centros de mercado y distribución al por menor") e, com isso, passou a ser considerado como o autor que deu a maior contribuição à Teoria das Localidades Centrais (TLC), tanto do ponto de vista teórico como por meio de estudos empíricos. Essa contribuição foi sistematizada por Ablas (1982) em três linhas diferentes.

A primeira diz respeito à contribuição teórica derivada do relaxamento de algumas hipóteses restritivas colocadas por Christaller e Losch como, por exemplo, o reconhecimento de que a distribuição da população não é homogênea e há possibilidade de haver lucro para aquelas empresas que estáo localizadas em posiçóes convenientes no espaço (vantagens locacionais), assim como há possibilidade de algumas localidades centrais especializarem-se na oferta de determinado produto. A segunda refere-se às tentativas de comparação entre as formulaçóes de Christaller e Losch e as teorias que procuram determinar hierarquia dos centros urbanos, pois Berry parte da ideia de que, de um lado, centros de determinada ordem não precisam ter, necessariamente, a mesma população, podendo existir pequenas variaçóes de tamanho e, de outro, que o desenvolvimento das localidades centrais não está diretamente relacionado ao tamanho de sua população. A terceira e última linha do raciocínio de Berry corresponde àquela que procura demostrar que o comércio varejista é o intermediário entre a produçáo e o consumo e, na medida em que se estuda a distribuição de bens, é possível definir algumas leis sobre a organização dos centros urbanos.

Encerrada a apresentação dos cinco principais autores e suas respectivas formulações e modelos teóricos a respeito da localização das atividades econômicas no espaço geográfico, bem como a contribuição de Berry, elabo- 
ramos um quadro-síntese (Quadro 1) para apresentar uma visão comparada entre as hipóteses, os fatores locacionais, princípios etc., de cada um deles.

Quadro 1 - Síntese dos expoentes das teorias de localização

\begin{tabular}{|c|c|c|c|c|c|}
\hline & Obra & \begin{tabular}{|c|}
$\begin{array}{c}\text { Atividade } \\
\text { econômica }\end{array}$ \\
\end{tabular} & Orientação & $\begin{array}{c}\text { Fatores } \\
\text { locacionais }\end{array}$ & Princípio \\
\hline $\begin{array}{l}\text { Johann Hen- } \\
\text { rich Von Thü- } \\
\text { nen }(1826)\end{array}$ & $\begin{array}{l}\text { O Estado } \\
\text { Isolado }\end{array}$ & Agricultura & $\begin{array}{l}\text { Minimi- } \\
\text { zaçáo de } \\
\text { custos } \\
\text { (Oferta) }\end{array}$ & $\begin{array}{l}\text { Custos de } \\
\text { transporte }\end{array}$ & $\begin{array}{l}\text { Determina a composiçáo de cul- } \\
\text { turas que maximizava a renda da } \\
\text { terra em funçáo da distância da } \\
\text { área de mercado }\end{array}$ \\
\hline $\begin{array}{l}\text { Alfred Weber } \\
(1909)\end{array}$ & $\begin{array}{l}\text { Teoria de } \\
\text { localizaçãoo } \\
\text { das indús- } \\
\text { trias }\end{array}$ & Indústria & $\begin{array}{l}\text { Minimi- } \\
\text { zação de } \\
\text { custos } \\
\text { (Oferta) }\end{array}$ & $\begin{array}{l}\text { Custos de } \\
\text { transpor- } \\
\text { tes; mão } \\
\text { de obra; e } \\
\text { fatores aglo- } \\
\text { merativos }\end{array}$ & $\begin{array}{l}\text { Determina a localizaçáo ótima } \\
\text { da indústria, que corresponde } \\
\text { àquela em que há menor custo } \\
\text { de transporte. }\end{array}$ \\
\hline $\begin{array}{l}\text { Walter } \\
\text { Christaller } \\
(1933)\end{array}$ & $\begin{array}{l}\text { Lugares } \\
\text { Centrais } \\
\text { no Sul da } \\
\text { Alemanha }\end{array}$ & $\begin{array}{l}\text { Comércio e } \\
\text { serviços }\end{array}$ & $\begin{array}{l}\text { Minimi- } \\
\text { zação de } \\
\text { custos de } \\
\text { desloca- } \\
\text { mento } \\
\text { (Oferta) } \\
\end{array}$ & $\begin{array}{l}\text { Custos de } \\
\text { transportes } \\
\text { e economias } \\
\text { de aglome- } \\
\text { raçáo }\end{array}$ & $\begin{array}{l}\text { Determina as leis gerais dos } \\
\text { padróes de povoamento, classi- } \\
\text { ficando as localidades de acor- } \\
\text { do com as suas funçóes e com } \\
\text { a complexidade dos bens que } \\
\text { oferecem. }\end{array}$ \\
\hline $\begin{array}{l}\text { August Losch } \\
\text { (1939) }\end{array}$ & $\begin{array}{l}\text { A economia } \\
\text { da localiza- } \\
\text { ção }\end{array}$ & Indústria & $\begin{array}{l}\text { Maximi- } \\
\text { zação de } \\
\text { lucros (De- } \\
\text { manda) }\end{array}$ & $\begin{array}{l}\text { Custos de } \\
\text { transportes } \\
\text { (tarifas } \\
\text { uniformes) }\end{array}$ & $\begin{array}{l}\text { Elabora uma teoria geral do equi- } \\
\text { líbrio das localizaçóes em um } \\
\text { sistema econômico, estudando } \\
\text { as relaçôes de interdependência } \\
\text { existentes entre as localizaçóes } \\
\text { individuais e o equilíbrio espacial } \\
\text { geral. }\end{array}$ \\
\hline $\begin{array}{l}\text { Walter Isard } \\
(1956)\end{array}$ & $\begin{array}{l}\text { Localização } \\
\text { e espaço } \\
\text { econômico }\end{array}$ & Indústria & $\begin{array}{l}\text { Minimi- } \\
\text { zação de } \\
\text { custos } \\
\text { (Oferta) }\end{array}$ & $\begin{array}{l}\text { Custos de } \\
\text { transporte, } \\
\text { de trans- } \\
\text { missão e de } \\
\text { produçáo }\end{array}$ & $\begin{array}{l}\text { Sintetiza as teorias anteriores e } \\
\text { propóe um modelo mais geral e } \\
\text { abrangente. }\end{array}$ \\
\hline
\end{tabular}

* Não incluímos Berry no quadro, porque ele não formulou uma teoria, somente aplicou na realidade. Fonte: Elaboração própria.

Feita a apresentação das principais teorias locacionais existentes de modo a indicar os fatores considerados como determinantes para a escolha da localização ótima, bem como os princípios e pressupostos dos autores que as elaboraram, temos base para introduzir a discussáo dos novos fatores loca- 
cionais, das novas tendências e perspectivas de análise da questão locacional no período atual.

\section{Do espaço absoluto e relativo ao relacional}

Muitas vezes, e a partir de agora cada vez mais, tem se feito necessária uma tentativa de explicação do real simultaneamente a uma revisão do arcabouço teórico que herdamos. Assim, empreendemos uma síntese da emergência da questáo locacional e das principais teorias locacionais, em que demonstramos que os modelos clássicos de localização atribuíam ao custo de transporte um papel fundamental para compreender a distribuiçáo espacial das atividades econômicas, além de ter como base o comportamento otimizador dos agentes econômicos, seja por meio da minimização dos custos ou pela maximizaçáo dos lucros.

Para compreender os processos urbanos sob a égide do modo de produção capitalista, Harvey (1980 [1973]) ressalta a importância de refletir sobre a natureza do espaço e, para tanto, identifica uma divisáo tripartite no modo como o espaço pode ser entendido:

Se considerarmos o espaço como absoluto ele se torna uma 'coisa em si mesma’, com uma existência independente da matéria. Ele possui entáo uma estrutura que podemos usar para classificar ou distinguir fenômenos. A concepçáo de espaço relativo propóe que ele seja compreendido como uma relação entre objetos que existe pelo próprio fato de os objetos existirem e se relacionarem. Existe outro sentido em que o espaço pode ser concebido como relativo e eu proponho chamá-lo espaço relacional - espaço considerado, à maneira de Leibniz, como estando contido em objetos, no sentido de que um objeto pode ser considerado como existindo somente na medida em que contém e representa em si mesmo as relaçôes com outros objetos (Harvey, 1980 [1973], p. 13, grifos nossos).

A partir da revisão das teorias clássicas sobre o tema da localização das atividades econômicas, realizada no tópico anterior, observamos de que maneira as concepçóes de espaço absoluto e relativo estiveram presentes, enquanto, no período contemporâneo, a perspectiva relacional se faz cada vez 
mais necessária para a compreensão de uma realidade cujas relações e interaçôes são cada vez mais complexas. O surgimento do pensamento relacional na Geografia Econômica se viu reforçado pelas mudanças na organização das empresas nas últimas décadas, e é resultado da maneira como, de modo geral, os geógrafos passaram a conceber o espaço (Parnreiter, 2018).

En la geografía económica relacional no se entiende en calidad de ciencia del espacio, sino como una ciencia de la acción que analiza de qué maneras, por qué y con qué resultados los actores producen su entorno: los espacios económicos (p.192).

Assim, compreender as transformações econômicas e as estratégias das empresas em sua complexidade e, não como fenômenos abstratos e despersonalizados, tal como nas formulaçôes teóricas clássicas, é necessário dar mais atenção aos agentes econômicos e ao papel que exercem no espaço geográfico, isto é, como, quando e onde atuam. Quando analisado sob a perspectiva relacional, o espaço náo é fixo, mas sim considerado em relação com os processos e as interaçóes econômicas e os seus agentes. Em outras palavras, tenta-se, desse modo, analisar e explicar como as relaçóes subjacentes aos processos econômicos geram certos padróes de localização.

Parnreiter (2018) ressalta que a perspectiva espacial para abordar os processos e as estruturas econômicas não se desenvolveu de maneira suficiente na história do pensamento econômico e, basicamente, se limitou a apenas um aspecto espacial: o custo de superar a distância entre produtores e consumidores. Dessa forma, a Geografia era somente um fator de custo e, portanto, um obstáculo. Essa maneira de conceber a Geografia remonta às teorias de localização elaboradas desde a primeira metade do século XIX na Alemanha.

El propósito de los modelos de localización es conocer la razón por la que surgen ciertos patrones de localización de actividades económicas, la forma de descubrirla se sustenta en relacionar la ubicación de las instalaciones de producción con la extensión de los mercados (o, en otras palabras, con la distancia entre productor y consumidor). Por ende, las teorías de localización tratan dos aspectos geográficos, a saber: la distancia y el área (Parnreiter, 2018, p. 109). 
Quando observamos o modelo de Christaller, por exemplo, percebemos as localizaçóes absolutas e relativas por meio de um pensamento de natureza hierárquica segundo as funçôes que as localidades centrais desempenham. A ideia de relacional não está presente, porque embora o modelo se baseie em fluxos e interaçôes, eles estão despersonalizados. Quando incluímos as pessoas, as relaçôes e interaçôes se tornam mais complexas por uma série de razóes. Entre elas, o fato de que, segundo essa teoria, quem mora na localidade $A$ vai até a localidade $B$ para adquirir produtos e serviços náo existentes em $\mathrm{A}$ e, se esses produtos e serviços existirem em $\mathrm{A}$, as pessoas vão se restringir a essa situação geográfica. Em síntese, essa teoria pauta-se na ideia de que todos estariam dispostos a fazer o menor percurso.

$\mathrm{Na}$ época de elaboração das formulaçôes e modelos teóricos locacionais, o custo de transporte exercia uma influência bastante significativa sobre a localização, especialmente quando a relação entre custos totais de produção e tarifa de transporte variava muito entre os diferentes pontos do espaço geográfico. Deste modo, a localizaçáo que possibilitava o lucro máximo para o empreendimento era aquela em que os custos de transporte eram minimizados, enquanto, do ponto de vista do consumidor, o esforço mínimo em relação ao deslocamento, baseando-se também no custo de transporte, era considerado. Em grande medida, essa perspectiva está fundada no pressuposto de que há boa oferta de transportes e, assim frisamos, mais uma vez, que a realidade socioespacial desigual de nossas cidades e entre as nossas regióes constitui fator adicional a ser ponderado na análise espacial.

À parte essa especificidade, diante de um contexto fortemente globalizado e com relaçóes e interaçóes cada vez mais complexas, as teorias locacionais elaboradas nos séculos XIX e XX não são suficientes para explicar a distribuição espacial das empresas e indústrias no período contemporâneo. Se considerarmos a forma original dessas teorias, estaremos nos distanciando muito da realidade que é diversa e mais complexa do que a superfície completamente homogênea que pressupóem os autores.

Sua adaptação às novas condiçôes resulta em uma tarefa bastante delicada. Contudo, quando devidamente situadas e relativizadas em seus respectivos contextos e analisadas de maneira crítica, sobretudo em relaçáo à concepção de espaço homogêneo, às áreas de mercado como hexagonais perfeitos e ao comportamento otimizador dos agentes econômicos e consumidores, essas teorias se têm valor para enriquecer o entendimento geográfico da so- 
ciedade, isto é, fortalecer nossa compreensão sobre as diferentes formas de espacialização da sociedade.

Além disso, considerar a perspectiva relacional no estudo sobre como as relaçôes socioespaciais dos agentes se entrelaçam com as estruturas da economia implica, primeiramente, em nunca considerar o objeto por si mesmo, isto é, de maneira individual, mas sim a partir das relaçóes que estabelecem. "Los actores económicos, sean personas o empresas, no son entidades atomísticas, sino sujetos interdependientes cuyos activos - que les permiten actuar - son constituidos por y en sus relaciones con otros actores" (Parnreiter, 2018, p. 195).

Segundo, a valorização do entendimento das relaçóes estabelecidas entre os diversos agentes que atuam na produção do espaço urbano e na determinação da localização que melhor atenda aos interesses relacionados ao desempenho econômico do capital, demanda uma análise multiescalar, ou seja consideração de várias escalas geográficas e, mais do que isso, interescalar, para avaliar como os movimentos entre empresas, agentes políticos e sujeitos sociais ocorrem entre as escalas geográficas estabelecidas até o âmbito global.

Por último, a perspectiva relacional implica também em uma mudança na metodologia de pesquisa; isto é, ao estudar as práticas (espaciais e econômicas) dos agentes, é necessário alterar as perguntas que se fazem: como e o por que se tornam mais importantes do que o quanto e o onde, sem, no entanto, desconsiderar a relevância da combinação de metodologias qualitativas e quantitativas para complementar e a aprofundar a análise do objeto de estudo.

\section{Consideraçóes finais}

As duas principais críticas que fazemos às teorias locacionais são, primeiro, a compreensáo limitada de espaço enquanto uma mera distância a ser superada entre produtores e consumidores, além da concepçáo predominante do espaço como sendo absoluto, e, em segundo lugar, a racionalidade dos agentes econômicos. A escolha da localização de uma empresa é decisão de um ou vários agentes e é determinada com base em mais motivos do que somente a busca pelo equilíbrio entre custos e gastos. Seus interesses são muito mais complexos e, às vezes, até mesmo contraditórios. Os agentes econômicos, sejam eles empresas, poder público ou citadinos/consumidores, 
são complexos em suas açôes. Eles atuam, pensam e sentem, ponderam e avaliam, tomam decisóes segundo critérios racionais e irracionais.

A preocupação com a escolha da localização que melhor atenda aos interesses das empresas e indústrias sempre foi latente, porém a diferença em relação às formulaçóes e aos modelos teóricos sobre a localização de atividades econômicas é que esses autores consideravam o custo dos transportes como fator fundamental para determinação da localização ótima, enquanto no período contemporâneo, por outro lado, podemos identificar outros fatores que se tornaram mais importantes na medida em que esse fator relativamente perde importância devido ao fenômeno da globalização e unicidade da técnica (Santos, 1996) no espaço geográfico.

O que temos de novo no período contemporâneo é que, em virtude do acirramento da concorrência, do aumento do poder de consumo e da mobilidade da população e, consequentemente, do poder de escolha, a preocupaçáo dos empresários deixou de ser somente com a localização ótima do ponto de vista da acessibilidade e do fluxo de pessoas.

Portanto, as mudanças que têm ocorrido nas últimas décadas, por meio da modernizaçáo no modo de produção e nas formas de comercialização e consumo, têm exposto as limitaçóes dos enfoques tradicionais sobre a localização das atividades econômicas e é crescente as dificuldades para explicar o comportamento locacional dos indivíduos e empresários diante de práticas espaciais cada vez mais complexas.

Resta como questão a orientar novas pesquisas em que medida as mudanças que marcam o período contemporâneo alteram a própria ideia de hierarquia urbana, centrada no primado da importância das localidades centrais, uma vez que, na pesquisa realizada, quando se toma como análise os investimentos feitos nem sempre dada ordem, da maior para a menor localidade, foi o fator principal a definir a escolha locacional.

Esperamos que os leitores desse livro, ao se debruçarem sobre os demais capítulos, possam avançar no debate que apresentamos neste texto.

\section{Referências}

ABLAS, Luiz Augusto Queiroz. A Teoria do Lugar Central: Bases teóricas e evidências empíricas. Estudo do caso de São Paulo. São Paulo: Instituto de Pesquisas Econômicas da Faculdade de Economia e Administração da Universidade de São Paulo (IPE-USP), 1982. 
ALVES, Flamarion Dutra. "Questôes teórico-metodológicas entre geografia econômica e desenvolvimento regional”. Caderno Prudentino de Geografia, v. 1, n. 37, pp. 5-21, 2015. AZZONI, Carlos Roberto. Teoria da localização. Uma análise crítica: a experiência de empresas instaladas no Estado de São Paulo. (Dissertação) São Paulo: Universidade de São Paulo, 1982.

BAILLY, Antoine. La organización urbana: Teorias y modelos. Madri: Nuevo Urbanismo, 1978. BERRY, Brian. Geografía de los centros de mercado y distribución al por menor. Barcelona: Vicens-Vives, 1971 [1967].

BRADFORD, M. G. e KENT, W. A. “Teoria dos lugares centrais: O modelo de Christaller”. Geografia Humana: Teorias e Aplicaçóes. Lisboa: Gradiva, 1987, pp. 17-45.

BRAGA, José Carlos de Souza. Alemanha: império, barbárie e capitalismo avançado. Sáo Paulo: Editora Vozes, 1999.

BRAGA, Rhalf Magalhães. "Tendências e perspectivas das teorias locacionais no período contemporâneo”. In: Geografares, n. 6, 2008, pp.167-179.

CAMAGNI, Roberto. Economía Urbana. Barcelona: Antônio Bosh, 2005.

CHRISTALLER, Walter. Central Places in Southern Germany. Londres: Prentice Hall, 1966. Tradução de Mario Antônio Eufrásio, 1981.

CORREAA, Roberto Lobato. "O enfoque locacional na Geografia”. Terra Livre, n. 1, 1986, pp. 62-66.

COUTINHO, Clarisse. "Escolha locacional das atividades financeiras: Uma análise das teorias de localização”. In: Seminário de Pós-Graduação em Geografia. 2009, Rio Claro. Anais [...]. Rio Claro: Universidade Estadual Paulista, 2009, pp. 307-318.

DOBB, Maurice Herbert. A evolução do capitalismo. Tradução de Manuel do Rêgo Braga. São Paulo: Abril Cultural, 1983.

DONDA Jr, Alberto. Fatores influentes no processo de escolha da localização agroindustrial no Paraná: Estudo de caso de uma agroindústria de aves. (Dissertação). Florianópolis: Universidade Federal de Santa Catarina, 2002.

EUFRÁSIO, Mario Antônio. A estrutura da Teoria dos Lugares Centrais de W. Christaller. (Dissertação). São Paulo: Universidade de São Paulo, 1981.

FAJARDO, Sérgio. "A questão locacional e a Nova Geografia”. Ambiência Guarapuava, v. 6, n. 1, 2010, pp. 161-68.

HAGGETT, Peter. Modelos de estructura locacional. In: Análisis locacional en la Geografía Humana. Tradução de J. Obiols. Barcelona: Gustavo Gili, 1976, pp. 41-3.

Métodos de análisis locacional. In: Análisis locacional en la Geografía Humana. Tradução de J. Obiols. Barcelona: Gustavo Gili, 1976, p.239-241.

. "Modelos en Geografía”. In: Geografía: Una síntesis moderna - Tradução de Maravillas Nájar e Graziana Ramazzini. Barcelona: Omega, 1994 [1983], p. 21.

HARVEY, David. A justiça social e a cidade. São Paulo: Hucitec, 1980 [1973].

MORAES, Antônio Carlos Robert de e COSTA, Wanderlei Messias da. Geografia Crítica: A valorização do espaço. São Paulo: Hucitec, 1987.

PARNREITER, Christof. "La geografía económica antes de la geografía económica: las teorías de localización”. In:___ Geografía económica: Una introducción contemporánea. México: Universidad Nacional Autónoma de México, 2018, pp. 108-23. 
"La geografía económica relacional". In: Geografía económica: Una introducción contemporánea. México: Universidad Nacional Autónoma de México, 2018, pp. 190-196.

RICHARDSON, Harry. Economia Regional. Teoria da localização, estrutura urbana e crescimento regional. Rio de Janeiro: Zahar, 1975.

SANTOS, Milton. A natureza do espaço: Técnica e tempo. Razão e emoção. São Paulo: Hucitec, 1996.

SANTOS, Flaviane Ramos dos. "Questão locacional e teorias de localização: contextualização e análise de sua validade no período contemporâneo". Caderno Prudentino de Geografia, Presidente Prudente, n. 40, v. 2, pp. 120-42, jul./dez. 2018.

SPOSITO, Maria Encarnação Beltrão. "Cidades médias: Reestruturação das cidades e reestruturação urbana”. In: (Org.). Cidades médias: Espaços em transição. São Paulo: Expressão Popular, 2007, pp. 233-53.

. "Reestruturação econômica, urbana e da cidade: Os papéis intermediários de cidades médias em múltiplas escalas”. In: LAN, Diana et al (Org.). Reestructuración productiva e industria en ciudades intermedias de Argentina y Brasil. Tandil: Universidad Nacional del Centro de la Provincia de Buenos Aires, 2018, pp. 189-207.

VALBUENA, Luís Guillermo Bezerra. "Aproximaciones microeconómicas en la Teoría de los Lugares Centrales de Christaller". Ensayos sobre política económica, v. 31, n. 70, pp. 67-120, 2013. 